\title{
Potential strategies for preventing chronic postoperative pain: a practical approach: Continuing Professional Development
}

\author{
Philippe Richebé, MD, PhD • Marco Julien, MD • Véronique Brulotte, MD
}

Received: 20 March 2015/Revised: 21 August 2015/Accepted: 16 September 2015/Published online: 19 October 2015

(C) Canadian Anesthesiologists' Society 2015

\begin{abstract}
Purpose This manuscript proposes pharmacological strategies that might decrease persistent postsurgical pain (PPSP). These recommendations are based on a review of current publications available in the literature.

Principal findings Persistent postsurgical pain has been defined by the International Association for the Study of Pain as clinical discomfort that lasts more than two months after surgery. Recent reviews reported that 10-50\% of patients develop chronic pain after surgery, 2-10\% with disabling chronic pain at six months. Preventive interventions should target all types of surgery, but specific attention should be placed on surgical insults that carry a high risk of pain chronicization. Regional anesthesia (RA) should be used whenever feasible, and a continuous perineural/epidural local anesthetic infusion is preferred over a single-shot technique. The RA should be initiated prior to the surgical incision and then continued for at least 24-72 hr after the surgery. Perioperative opioids should be used for nociceptive stimuli not managed by the RA. An intravenous infusion of ketamine, an $N$ methyl-D-aspartate receptor (NMDA) antagonist, might be added for a further decrease in neuronal sensitization, especially when the procedure is extensive or when $R A$ is not feasible or contraindicated. A multimodal approach is always suggested. The literature still does not strongly support the use of gabapentinoids for PPSP prevention; however, they might be maintained in patients who use them preoperatively.
\end{abstract}

P. Richebé, MD, PhD ( $\square)$ · M. Julien, MD · V. Brulotte, MD Department of Anesthesiology, Hospital MaisonneuveRosemont, University of Montreal, 5415 Boulevard de l'Assomption, Montreal, QC H1T 2M4, Canada

e-mail: philipperichebe@live.com
Conclusions A winning strategy to reduce the incidence of PPSP may well involve performing minimally invasive surgery, providing adequate perioperative analgesia based on $R A$, and using a multimodal approach with NMDA antagonists.

\section{Objectives of this Continuing Professional Development (CPD) module:}

After reading this module, the reader should be able to:

1. Estimate the incidence of persistent postsurgical pain (PPSP);

2. Identify the risk factors for developing PPSP;

3. Describe the processes of peripheral and central sensitization that support the transition from acute to chronic pain after surgery;

4. Pinpoint the different pharmacological strategies available for the anesthesiologist in the perioperative period to impede the development of PPSP.

Chronic postoperative pain, also commonly called persistent postsurgical pain (PPSP), has been defined by the International Association for the Study of Pain (IASP) as a clinical discomfort that lasts more than two months after surgery. Other causes for pain such as chronic infection are excluded as is pain from a chronic condition preceding the surgery. ${ }^{1}$

The incidence of PPSP varies according to the type of surgery. Recent reviews from the last decade reported that $10-50 \%$ of patients might develop chronic pain after any of six "common surgical procedures" (amputation; breast surgery; thoracotomy; inguinal hernia repair; coronary artery bypass; Cesarean delivery), and that $2-10 \%$ present with disabling chronic pain (pain $>5$ out of a score of 10) at six months after the surgical insult. ${ }^{2,3}$ Other more recent 
reviews report similar incidence. ${ }^{4-7}$ Nevertheless, the definition used by the various authors to characterize PPSP plays a major role in the reported incidence. In 2012, Schug et al. reported that the prevalence was reduced from $40 \%$ to $18 \%$ when considering only moderate to severe pain (pain $>3$ out of a score of 10) in the area of the surgery. Also, the prevalence of PPSP was reduced to only $6 \%$ when patients who preoperatively complained of pain in the area of surgery were excluded. ${ }^{8}$

Persistent postsurgical pain affects millions of patients every year and is a potential burden for a healthcare system that must now be considered.

\section{Risk factors for PPSP}

The classical risk factors that have been described for the development of PPSP are preoperative pain, significant preoperative analgesic consumption, and high postoperative pain intensity. For example, amputees with high preamputation pain scores tend to have a higher rate of phantom limb pain. ${ }^{5}$ Age and sex have also been suggested to influence the development of chronic pain after surgery, with older men being less likely to develop PPSP.

Various preoperative screening tests have reported a correlation between the incidence of PPSP and the preoperative degree of catastrophizing ("tendency to exaggerated pessimism about outcome"), ${ }^{3}$ anxiety, fear of surgery and postoperative pain, lack of support in the patient's environment, and/or exaggerated response to experimental pain stimuli (quantitative sensory testing [QST]). Preoperative questionnaires designed to identify patients likely to develop PPSP as well as QSTs are impractical in the daily clinical context. ${ }^{9-11}$ Anesthesiologists facing fragile patients should be given more time to make a proper evaluation of their anxiety level during an appropriate consultation. Nevertheless, QSTs are still controversial in their ability to make a strong prediction regarding the development of PPSP. ${ }^{12}$

The intensity of acute postoperative pain has also been proposed as one risk factor that might induce PPSP. ${ }^{13}$ This association between PPSP and early postoperative high pain scores has been part of the rationale for using regional anesthesia (RA) techniques to block nociceptive input from the diseased and surgical area that leads to subsequent peripheral and central neuronal sensitization. But severe acute postoperative pain is not sufficient to explain PPSP on its own. Indeed, some patients with high acute postoperative pain scores do not develop chronic pain, while others with low pain scores due to aggressive multimodal perioperative analgesia do develop PPSP. This might be partly explained by some genetic variation between patients. Catecholamine-O-methyltransferase polymorphism is associated with variations in pain sensitivity; melanocortin-1 receptor gene polymorphism in red-haired females is associated with a higher response to some opioids. ${ }^{14}$ Nevertheless, single nucleotide polymorphism has not yet been correlated with the risk of developing chronic pain such as PPSP.

Two other factors might better explain why PPSP develops, specifically, the occurrence of nerve injury during surgery and the development of neuronal plasticity associated with peripheral and central sensitization. Issues related to nerve injury are beyond the scope of this present review but suffice it to say that it is the surgeon's responsibility to reduce the risk of nerve injury by using minimally, or at least less invasive surgical techniques when appropriate. Examples of surgical options that will very likely change the long-term outcome of the patients in terms of PPSP include preservation of the intercostobrachial nerve in mastectomy, minimally invasive nerve-sparing techniques for thoracotomies, more precise dissection of the inguinal area to avoid nerve damage, etc. ${ }^{3}$ Well-written reviews on the subject have been published during the last decade and can easily be found. ${ }^{15}$

Nevertheless, there are many patients without an obvious nerve injury who develop PPSP. Yet, they describe their PPSP with words similar to those used by patients suffering from neuropathic pain. It has very recently been proposed that the transition from acute to chronic postsurgical pain shares common mechanisms with the development of neuropathic pain.

Postoperative neuronal sensitization might be another physiological phenomenon that leads to neuropathic chronic pain in the surgical territory and beyond. ${ }^{16}$ Very recently a "nerve injury-induced neuropathic pain probability grading system" has been used to identify surgeries at high risk of neuropathic pain development. ${ }^{15}$ The prevalence of neuropathic pain was about $65 \%$ in thoracic and breast surgeries, $31 \%$ in groin hernia repair, and only $6 \%$ in orthopedic surgeries like total hip or knee arthroplasty.

Central sensitization is defined as "a form of synaptic plasticity in the spinal cord that amplifies pain signalling" 17 and finds its origin in surgical and perioperative noxious stimuli, inflammatory mediators, and glial activation. ${ }^{18-20}$ The central sensitization clinically translates into the socalled clinical hyperalgesia that can be measured after surgery. Postoperative early hyperalgesia, when measured, was correlated with a higher risk of developing PPSP. ${ }^{16,21}$ Also, long-term dysesthesia (hypo- or hyperesthesia) has been reported more frequently in patients with PPSP. ${ }^{6}$ 


\section{Mechanism of PPSP development}

The following is a brief review of the mechanisms that explain why surgery can induce neuronal sensitization and PPSP. This will help anesthesiologists choose the most appropriate strategies, among those proposed below, to offer patients in the perioperative period in an effort to avoid or reduce the development of PPSP.

Surgery acts as an intense and repeated peripheral painful stimulus inducing peripheral and central sensitization. At the central level, by changing the release of neurotransmitters in the spinal synaptic cleft, the high pain stimulus will modify the activity of pre- and postsynaptic receptors like $\alpha$-amino-3-hydroxy-5-methyl-4isoxazolepropionic acid receptors and N-methyl-Daspartate (NMDA) receptors. As a consequence of this sustained stimulation from the periphery, changes in gene transcription in sensory neurons (in dorsal root ganglia [DRG] and spinal cord) augment the release of postsynaptic transcription factors and proteins that will participate in enhancing neuronal excitability for days. Then neuronal plasticity continues over time and leads to changes in neuronal functions and structure, which explains PPSP. ${ }^{17,22-24}$ More recently, numerous authors have reported that glial cells (microglia and astrocytes), activated by the inflammatory response to the surgical insult, play an important role in the induction and maintenance of the central sensitization that leads to PPSP. ${ }^{19,20,23}$ Briefly, inflammation activates macrophages which activate microglial cells in DRGs and astrocytes in the central nervous system (CNS). Activated microglial cells induce an increase in pro-inflammatory cytokines such as interleukins (IL)-1 $\beta$, IL-6, tumour necrosis factor$\alpha$, and brain-derived neurotrophic factor. These cytokines contribute to the development of the neuronal central hyperexcitability that exists in neuropathic pain and PPSP.

Interestingly, anesthesia drugs might also be responsible for some activation of NMDA receptors and/or glial cells. More precisely, high doses of opioid have been reported to increase the level of central sensitization. In animals and human volunteer studies, this opioid-induced hyperalgesia $(\mathrm{OIH})$ was shown with all types of opioids used in anesthesiology during surgery (e.g., fentanyl, remifentanil, etc.). ${ }^{25-28}$ The implication of NMDA receptors in the development of $\mathrm{OIH}$ was reported early, ${ }^{29}$ and more recently, the ability of intraoperative opioids to activate glial cells was shown. ${ }^{19}$ Opioid-induced hyperalgesia was dose-dependent and time exposure-dependent. Clinical trials also reported $\mathrm{OIH}$ after surgery. ${ }^{30-35}$ Most studies reported only on higher pain scores, higher opioid consumption, and higher postoperative acute hyperalgesia for two or three days after the surgery when high intraoperative doses of opioids were administered. Only two studies reported on the influence of high doses of intraoperative opioids on the risk of developing PPSP. ${ }^{36}$ Better studies are required to draw a strong conclusion on whether acute OIH might participate in the development of PPSP, especially since most of the data are from animal studies and evidence in humans is less compelling, even if publications have been more numerous in recent years.

\section{Pharmacological strategies available for anesthesiologists to reduce the incidence of PPSP}

Although there is no doubt that perioperative multimodal analgesia is beneficial for acute pain management, there are still controversies on the role of nociception blockade (RA) and optimal control of acute postoperative pain to decrease the incidence of PPSP. In their review of the literature in 2012, Van de Ven et al. showed that the incidence of PPSP after amputation was not significantly changed by RA or any other type of preventive pharmacological strategies, but also that it was difficult to draw a definite conclusion regarding this specific type of surgery. ${ }^{5}$ This might be explained by the preexisting pain and the preoperative opioid exposure in this specific population. Nevertheless, their findings might not be true when we consider patients who undergo surgeries without preexisting pain or preexisting opioid consumption. These patients might benefit from the following preventive strategies:

\section{Regional anesthesia}

Regional anesthesia might be able to reduce the incidence of PPSP by different mechanisms: ${ }^{37} 1$ ) by blocking the transmission of the nociceptive input from the periphery to the central level and by limiting the neuronal inflammation that might activate glial cells, and 2) by allowing a strong reduction in intraoperative opioid doses that might decrease the so-called $\mathrm{OIH}$ and its possible long-term consequences. In 2012, Meleine et al. presented results of an experimental study in which a long-duration nerve block was able to prevent PPSP in animals better than a singleshot block. Nonetheless, the beneficial effect of this longduration nerve block was lost when high doses of opioids were used during the anesthesia. ${ }^{38}$ Hence, anesthesiologists might choose the option of providing an adequate RA to allow for a significant decrease in the intraoperative doses of opioids.

In the clinical setting, it might be interesting to differentiate neuraxial RA, such as epidural analgesia, from peripheral nerve blocks. The epidural analgesia has been recommended for many years as the gold standard to manage acute postoperative pain in major surgeries such as thoracotomies and laparotomies. In these surgeries, it has 
also been reported that epidural analgesia was able to reduce PPSP. ${ }^{32,39,40}$ In a meta-analysis published in 2013, Andreae et al. analyzed 23 clinical trials that included 1,090 patients followed for six months postoperatively and 441 patients followed for one year after surgery. The aim of these clinical trials was to evaluate the impact of epidural analgesia on the development of PPSP. The data from Andreae et al. favoured epidural analgesia to decrease PPSP in thoracotomies and abdominal surgeries (odds ratio [OR] 0.33 ) as well as paravertebral blocks in breast surgeries (OR 0.37). ${ }^{41}$ No data were reported on how long the epidural should be used in order to have a significant impact on PPSP.

Regarding the peripheral nerve blocks, reviews ${ }^{41}$ concluded that the small number of studies and patients and the multiple biases (multiple surgeries, multiple regional nerve blocks...) did not allow drawing any conclusion on the impact of peripheral regional nerve blocks on PPSP.

Nevertheless, one observational study reported that general anesthesia (GA) is a risk factor for the development of higher acute pain scores after total hip or knee surgeries (OR 8.5 for pain at rest and OR 9.0 for movement-related pain) when compared with patients who had surgery under RA. ${ }^{42}$ The same patients were followed longitudinally, and the authors claimed that, compared with GA, RA was able to reduce the risk of PPSP one year after surgery (OR 2.5 favouring RA) ${ }^{43}$ Nevertheless, these two studies combined epidural and peripheral nerve blocks in the RA group, casting a persistent doubt on the utility of peripheral nerve blocks to limit the development of PPSP.

In conclusion, regarding RA, we might agree that regional techniques provide better pain relief for acute postoperative pain. Most of the reviews published during the last decade generated controversies and struggled to give a strong conclusion regarding whether RA could decrease the incidence of PPSP. If it might seem reasonable to recommend epidural analgesia in order to decrease PPSP, the impact of peripheral nerve blocks must still be proven. Future well-designed studies are warranted. The role of RA on immunomodulation and neuronal sensitization must also be studied.

\section{Ketamine}

Recent systematic reviews and meta-analyses reported that administering the NMDA antagonist ketamine perioperatively can reduce acute postoperative pain. ${ }^{44}$ It has also been shown that ketamine was able to reduce the socalled $\mathrm{OIH}^{34}$ for $48 \mathrm{hr}$ after major laparotomy without epidural analgesia. The most common regimen for intravenous administration of ketamine was 0.2-0.5 $\mathrm{mg} \cdot \mathrm{kg}^{-1}$ at the induction of anesthesia, followed by half the bolus dose every hour and none during the last hour of surgery. Ketamine is sometimes added to the patientcontrolled analgesia $\left(0.5-1 \mathrm{mg} \cdot \mathrm{mL}^{-1}\right)$ for $48 \mathrm{hr}$ or given as a single drug in a separate infusion $\left(0.2 \mu \mathrm{g} \cdot \mathrm{kg}^{-1} \cdot \mathrm{min}^{-1}\right)$, which might be seen as more cumbersome and difficult to offer during the hospital stay.

During the last decade, there have been conflicting results regarding the role of intravenous ketamine to prevent PPSP when administered during surgery only or during surgery plus for a few days following surgery. One well-designed study showed positive results in laparotomies at a time when epidural anesthesia was not widely used for major abdominal surgery. ${ }^{45}$ One very recent systematic review and meta-analysis offered a good summary of the few studies published on this topic. ${ }^{46}$ In their article, Klatt et al. found only ten papers in the literature to include in their comprehensive meta-analysis, with only 784 patients in total. Three papers (303 patients) showed a positive impact concerning PPSP. They wrote: "In the analysis, only one of nine pooled estimates of postoperative pain at rest or in motion after one, three, six or 12 months, defined as a value $\geq 3$ on a visual analogue scale of $0-10$, indicated a marginally significant pain reduction." They concluded that the current evidence is not sufficient to support the perioperative administration of ketamine for reducing chronic postsurgical pain.

Again, as is the case for RA, the difficulty to conduct clinical studies on the effect of ketamine on PPSP resulted in a paucity of clinical trials, small numbers of studied patients, and multiple biases. It is therefore difficult to draw any firm conclusion from the available data. It follows that further studies are warranted here too.

\section{Other NMDA modulators}

Nitrous oxide $\left(\mathrm{N}_{2} \mathrm{O}\right)$ is also an NMDA antagonist and has been shown to reduce acute OIH after surgery in rodents ${ }^{47}$ and in humans. ${ }^{48}$ Nevertheless, there is a lack of clinical trials evaluating the role of $\mathrm{N}_{2} \mathrm{O}$ to reduce PPSP. One retrospective analysis of data from a study designed for other purposes suggested a likely preventive effect of $\mathrm{N}_{2} \mathrm{O}$ to decrease PPSP. ${ }^{49}$ This does not allow us to recommend $\mathrm{N}_{2} \mathrm{O}$ administration during anesthesia for the purpose of decreasing the incidence of PPSP.

Magnesium is an ion which is the "natural blocker" of the NMDA receptor when this receptor is "at rest", i.e., not activated. Once the NMDA receptor is activated, the magnesium ion leaves the receptor and allows a calcium ion flow to enter the post-synaptic neuron at the central spinal level, which starts the process of central sensitization. Magnesium administration was thought to be a likely strategy to block NMDA receptors in the CNS in order to decrease acute and perhaps chronic pain. For many years, 
animal studies suggested that intrathecal magnesium was able to block acute pain and hyperalgesia after surgery. Recent reviews of the literature in humans showed that intrathecal magnesium does allow for an interesting decrease in postoperative acute pain,$^{50}$ but intravenous magnesium was less potent. ${ }^{51}$ The fact that intravenous magnesium was less convincing to decrease acute postoperative pain might be explained by one clinical trial from Mercieri et al. ${ }^{52}$ In their study, the authors reported that intravenous magnesium did not properly cross the blood-brain barrier and, thus, could hardly be expected to decrease acute postoperative pain if this effect relied on its activity at the CNS level. Regarding PPSP, there is a lack of studies evaluating the impact of magnesium on such long-term outcome.

\section{Gabapentin and pregabalin}

Gabapentinoids produce an inhibitory modulation of neuronal excitability by blocking the $\alpha 2-\delta$ subunit of the presynaptic voltage-dependent calcium channels which are upregulated in central sensitization processes. Their efficacy in the treatment of chronic pain of neuropathic origin is well recognized, but their role in preventing PPSP is still debated. Blocking these central presynaptic targets might decrease the neuronal excitability that occurs when a high acute pain level exists during and after surgery.

Clinical trials brought some controversial results regarding a reduction in the incidence of PPSP with gabapentin at three and six months after thoracotomy, Cesarean delivery, cardiac and breast surgery, and amputation. On the other hand, two reviews indicated that pregabalin significantly reduced the incidence of PPSP after cardiac, spine, thyroid, and knee surgery at three months (OR, 0.70; 95\% confidence interval [CI], 0.51 to $0.95^{53}$ and OR, $0.09 ; 95 \%$ CI, 0.02 to $0.079^{54}$ ). Pregabalin $150-300 \mathrm{mg}$ was administered prior to surgery and continued (75-150 mg bid) for two to 14 days. The efficacy of pregabalin in reducing the incidence of PPSP seems to be more obvious than that for gabapentin, although more studies are required to confirm this assessment. ${ }^{55}$

\section{COX-inhibitors}

There is no doubt that non-steroidal anti-inflammatory drugs and acetaminophen are part of the multimodal perioperative acute pain management strategy. Nevertheless, there is no strong evidence that these medications prevent PPSP.

\section{Alpha-2 agonists}

Clonidine, an alpha-2-adrenergic agonist, is often used to treat acute or chronic pain despite its hemodynamic side effects. Animal studies and also clinical trials showed interesting results regarding postoperative acute pain and hyperalgesia following intravenous or intrathecal clonidine administration. Nevertheless, studies evaluating the effect of perioperative administration of clonidine on PPSP are thus far lacking.

\section{Conclusion on perioperative strategies to reduce the risk of PPSP}

Persistent postsurgical pain is a complex bio-psycho-social phenomenon, and there is no fully validated preventive measure. Nevertheless, most of the interventions described above that have some potential to reduce the incidence of PPSP are easy for anesthesiologists to implement in their daily practice and can therefore be considered as usable options when there is a significant risk of PPSP.

Preventive interventions should target either (1) surgeries that carry a high risk of pain chronicization (e.g., limb amputation, radical mastectomy, thoracotomy, laparotomy, or when an injury to a major nerve is anticipated) or (2) operations with a moderate risk of pain chronicization in patients with significant risk factors (e.g., young age and female, high intensity of preoperative pain, and significant opioid use).

Regional anesthesia should be used whenever feasible, especially in thoracotomy and radical mastectomy patients. A continuous perineural/epidural local anesthetic infusion is preferred over a single-shot technique. Some evidence favours initiation of the infusion before the surgical incision and then continuing it for at least 24-72 hr following the surgery. High intraoperative doses of opioids might be better avoided when possible. Perioperative opioids should be used on an as needed basis for nociceptive stimuli not covered by the RA.

An intravenous ketamine infusion can be added to decrease central sensitization further, especially when the procedure is extensive or requires the use of opioids despite effective RA, or when RA is not feasible/contraindicated.

On top of regional analgesia, a multimodal approach is suggested using acetaminophen, a non-steroidal antiinflammatory, and opioids when possible. Thus far, the literature does not support initiating gabapentinoids for PPSP prevention; however, they should be maintained in patients who use them preoperatively.

\section{Clinical scenario}

A 52-yr-old male is scheduled for an elective surgery to remove a distal esophageal cancer. The planned procedure is a distal esophagectomy via an Ivor-Lewis approach (i.e., 
supra-umbilical laparotomy and right thoracotomy). Except for his neoplastic disease, his medical record is positive only for chronic obstructive pulmonary disease of mild severity and decreasing tobacco consumption (from 25 to 12 cigarettes each day since his diagnosis). Past anesthesia experience for an appendectomy was uneventful. After discussion with the patient, you plan a general anesthesia induced with propofol $\left(2 \mathrm{mg} \cdot \mathrm{kg}^{-1}\right)$ and sufentanil $(0.2$ $\mu \mathrm{g} \cdot \mathrm{kg}^{-1}$ ) and maintained with desflurane (0.7-1 MAC). Muscle relaxation will be provided using rocuronium before tracheal intubation $\left(0.6 \mathrm{mg} \cdot \mathrm{kg}^{-1}\right)$ and as needed during surgery. You also plan to insert a thoracic epidural catheter before induction. Before entering the operating room, the patient tells you that his wife who had surgery for breast cancer last year still suffers from burning pain in the axillary area to this day. He expresses concerns about the possibility he might have to face the same situation.

\section{Instructions for completing the continuing professional} development (CPD) module:

1. Read the current article and the references indicated in bold.

2. Go to: http://www.cas.ca/Members/CPD-Online and select the current module (Potential strategies for preventing chronic postoperative pain: a practical approach: Continuing Professional Development).

3. Answer the multiple choice questions regarding the case scenario.

4. Once you have entered all of your answers, you will have access to experts' explanations for all the possible choices.

5. Participants may claim up to three hours of CPD for a total of 12 credits under Section 3 of the CPD program of the Royal College of Physicians and Surgeons of Canada.

\section{Stratégies potentielles pour la prévention des douleurs chroniques postchirurgicales: une approche pratique}

\author{
Résumé \\ Objectif Ce manuscrit, basé sur la littérature, propose \\ des stratégies pharmacologiques qui pourraient réduire les \\ douleurs chroniques postchirurgicales (DCPC).
}

Constatations principales Les DCPC ont été définies par l'International Association for the Study of Pain (IASP) comme un inconfort clinique qui dure plus de deux mois après la chirurgie. Des revues récentes de la littérature ont rapporté que 10 à $50 \%$ des patients manifestent des DCPC, 2 à $10 \%$ étant des DCPC handicapantes après six mois postopératoires. Des interventions préventives devraient cibler tous les types de chirurgie, mais une attention spécifique devrait être portée aux chirurgies qui sont associées à un haut risque de DCPC. L'anesthésie locorégionale (ALR) devrait être utilisée autant que possible en l'absence de contre-indication. Une perfusion continue périneurale/péridurale d'anesthésiques locaux est préférable à une injection unique. Elle devrait être amorcée avant l'incision chirurgicale puis maintenue pour au moins 24-72 h après chirurgie. Les opioïdes périopératoires devraient être utilisés pour traiter les stimuli nociceptifs non couverts par l'ALR. Une perfusion intraveineuse de kétamine pourrait être ajoutée pour réduire encore plus la sensibilisation neuronale, spécialement quand la procédure est importante ou quand l'ALR est contre-indiquée ou non réalisable. Une approche multimodale est bien sûr toujours recommandée. La littérature n'appuie pas particulièrement l'utilisation des gabapentinoïdes pour prévenir les DCPC. Cependant ils seraient à maintenir chez les patients qui les utilisent déjà en préopératoire.

Conclusion Le recours à des techniques chirurgicales minimalement invasives, l'utilisation d'une analgésie périopératoire basée sur l'ALR, une approche multimodale et les antagonistes N-méthyl-D-aspartate devraient constituer une stratégie permettant une réduction de l'incidence des DCPC.

\section{Objectifs de ce module de développement professionnel} continu

Après avoir lu ce module, le lecteur devrait être capable de:

1. Estimer l'incidence des douleurs chroniques postchirurgicales (DCPC)

2. Identifier les facteurs de risque de développement des DCPC

3. Décrire les processus de sensibilisation périphérique et centrale qui supportent la transition de la douleur aiguë à la douleur chronique (DCPC)

4. Nommer les différentes stratégies pharmacologiques disponibles pour l'anesthésiologiste dans la période périopératoire pour s'opposer au développement de DCPC.

Les douleurs chroniques après chirurgie sont aussi communément appelées douleurs chroniques postchirurgicales (DCPC). Les DCPC ont été définies par 
l'International Association for the Study of Pain (IASP) comme un inconfort clinique qui dure plus de deux mois après la chirurgie. Les autres causes de douleur comme les infections chroniques ou des douleurs chroniques préexistantes à la chirurgie doivent être exclues de cette définition. ${ }^{1}$ L'incidence des DCPC varie en fonction du type de chirurgie. Les revues récentes issues de la dernière décennie rapportent que 10 à $50 \%$ des patients manifestent des douleurs chroniques après six «chirurgies communes» (amputation, chirurgie du sein, thoracotomie, hernie inguinale, pontages coronariens, césarienne), et que 2 à $10 \%$ de ces patients présentent des douleurs chroniques handicapantes (douleur $>5$ sur 10 ) à six mois de la chirurgie., ${ }^{2,3}$

D'autres revues plus récentes rapportent une incidence similaire. ${ }^{4-7}$ Néanmoins, la définition elle-même de DCPC joue un rôle majeur dans l'incidence rapportée par les auteurs. Schug et coll. rapportent en 2012 que la prévalence de DCPC est réduite de $40 \%$ à $18 \%$ quand on considère seulement les DCPC modérées à graves (scores de douleur de plus de 3/10) dans la zone opérée. Aussi, exclure les patients qui se plaignent de douleurs préexistantes à la chirurgie dans la zone opérée mène à réduire la prévalence de DCPC à seulement $6 \% .^{8}$ Les DCPC touchent des millions de patients chaque année et sont un fardeau financier potentiel pour le système de santé, fardeau qui doit être pris en considération.

\section{Facteurs de risque des DCPC}

Les facteurs de risque classiquement décrits pour le développement de DCPC sont: douleur préopératoire, importante consommation préopératoire d'analgésiques et haute intensité de douleur postopératoire. C'est le cas par exemple pour les amputés, parmi lesquels ceux qui affichent de hauts scores de douleur préamputation sont aussi ceux qui tendent à développer plus souvent une douleur de type membre fantôme.

L'âge et le sexe ont aussi été proposés comme facteurs influençant le développement de DCPC, les hommes plus âgés étant moins à risque.

Différents tests préopératoires ont été proposés pour évaluer les patients et on rapporte une corrélation entre l'incidence de DCPC et la tendance à un pessimisme exagéré à propos du devenir postopératoire, ${ }^{3}$ l'anxiété, la peur de la chirurgie et de la douleur postopératoire, le manque de soutien de l'entourage et/ou la réponse exagérée à un stimulus expérimental (test quantitatif de sensibilité: «QST»).

Obtenir ces informations et réaliser ce type de test avant la chirurgie s'avèrent difficiles dans la pratique quotidienne de l'anesthésie. ${ }^{9-11}$ Plus de temps devrait cependant être consacré face à un patient fragile pour évaluer son niveau d'anxiété et ces facteurs psychologiques de façon appropriée. Aussi, les QST sont des tests dont la valeur prédictive pour le développement des DCPC reste controversée. ${ }^{12}$

De plus, l'intensité de la douleur aiguë postopératoire a été proposée comme étant un facteur de risque qui pourrait induire les DCPC. ${ }^{13}$ Cette association entre DCPC et scores élevés de douleur aiguë postopératoire a été la raison poussant au développement et à l'utilisation répandue des techniques d'anesthésie locorégionale (ALR) dans le but de mieux bloquer les influx nociceptifs provenant de la périphérie et ainsi limiter les processus de sensibilisation neuronale qui en découlent. Cependant, certains patients présentant de hauts scores de douleur aiguë postopératoire ne développent pas de DCPC alors que d'autres, soumis à une stratégie préventive vigoureuse et ne rapportant que de faibles scores de douleur aiguë, vont les développer. Ceci pourrait partiellement s'expliquer par des variations génétiques. Le polymorphisme de la catécholamine-O-méthyltransférase est associé à des variations de sensibilité à la douleur; le polymorphisme du gène codant pour le récepteur à la mélanocortine-1 chez les femmes rousses est associé à une réaction accrue à certains opioïdes. ${ }^{14}$ Néanmoins, le polymorphisme de simples nucléotides (SNP) n'a jamais été corrélé au risque de manifester des douleurs de type DCPC jusqu'à maintenant.

Il y a deux facteurs qui pourraient mieux expliquer pourquoi les DCPC apparaissent: la lésion nerveuse pendant la chirurgie et l'apparition d'une plasticité neuronale qui aboutit à une sensibilisation périphérique et centrale et aux DCPC. En ce qui concerne les lésions nerveuses, nous n'aurons pas la place ici pour explorer le sujet plus en détail. Il incombe au chirurgien de déployer tous les efforts et techniques pour réduire le risque de lésion nerveuse durant sa chirurgie. La préservation du nerf brachial intercostal dans les mastectomies, les thoracotomies minimalement invasives avec préservation des nerfs, des dissections plus précises de la région inguinale pour éviter le traumatisme nerveux etc. sont des exemples d'options chirurgicales qui, très probablement, changeront le pronostic du patient en termes de DCPC. $^{3}$ De très nombreuses revues ont été écrites sur le sujet durant la dernière décennie et sont disponibles. ${ }^{15}$

Il n'en reste pas moins que de nombreux patients développent des DCPC sans lésion nerveuse évidente. Ils décrivent néanmoins leur DCPC avec des mots similaires à ceux employés pour décrire une douleur de type neuropathique. On a récemment démontré que la transition d'une douleur aiguë vers une douleur chronique postchirurgicale semble partager des mécanismes 
communs avec le développement des douleurs neuropathiques.

La sensibilisation neuronale après chirurgie pourrait être un phénomène physiologique qui aboutit au développement de douleurs chroniques neuropathiques dans le territoire opéré et au-delà. ${ }^{16}$ Très récemment, un système d'évaluation de la probabilité de douleur neuropathique après chirurgie a été proposé par certains auteurs. ${ }^{15}$ La prévalence de douleurs neuropathiques après chirurgie était d'environ $65 \%$ en chirurgie thoracique et mammaire, $31 \%$ pour les hernies inguinales, et seulement de $6 \%$ en chirurgie orthopédique comme l'arthroplastie totale de la hanche ou du genou.

La sensibilisation centrale est définie comme «une forme de plasticité synaptique dans la corne dorsale de la moelle qui amplifie les signaux douloureux ${ }^{17}$ et trouve son origine dans les stimuli périopératoires, l'insulte chirurgicale et les médiateurs de l'inflammation et de l'activation gliale. ${ }^{18-20}$ Cette sensibilisation centrale se traduit cliniquement par une hyperalgésie clinique qui peut être mesurée après chirurgie. Cette hyperalgésie précoce après chirurgie, quand elle a été évaluée, a été corrélée avec un risque plus élevé de développer des DCPC. ${ }^{16-21}$ Aussi, des dysesthésies à long terme (hypo- ou hyperesthésies) sont plus fréquemment rapportées chez les patients qui présentent des DCPC. ${ }^{6}$

\section{Mécanismes physiologiques du développement des DCPC}

Nous devons ici rappeler les mécanismes qui expliquent pourquoi une chirurgie peut induire une sensibilisation neuronale et des DCPC. Ceci aidera les anesthésiologistes à choisir les stratégies les plus appropriées parmi celles proposées ci-dessous et qui peuvent être offertes aux patients dans la période périopératoire pour essayer de minimiser le développement de DCPC.

La chirurgie agit comme un stimulus douloureux intense et répété qui induit une sensibilisation périphérique et centrale. Au niveau central, en influençant la libération de neurotransmetteurs dans la fente synaptique, le haut niveau d'intensité douloureuse modifie l'activité de récepteurs pré- et postsynaptiques tels que les récepteurs de types acide $\alpha$-amino-3-hydroxy-5-méthyl-4-isoxazolepropionique (AMPA) et N-méthyl-D-aspartate (NMDA). À la suite de cette stimulation périphérique prolongée, des changements dans la transcription de certains gènes dans les neurones sensitifs (dans la corne et les ganglions dorsaux de la moelle) apparaissent et modifient la libération de certains médiateurs postsynaptiques principalement excitateurs. Le tout aboutit à une hyperexcitabilité neuronale qui peut durer plusieurs jours. Lorsqu'elle s'installe, cette plasticité neuronale entraîne des changements dans la fonction et la structure des neurones pouvant expliquer les DCPC. ${ }^{17,22-24}$ Plus récemment, de nombreux auteurs ont rapporté que les cellules gliales (microglie et astrocytes), activées par les réponses inflammatoires au traumatisme chirurgical, jouaient un rôle important dans l'induction et le maintien d'une sensibilisation centrale qui aboutit aux DCPC. 19,20,23 Brièvement, l'inflammation active les macrophages. Les macrophages activent les cellules microgliales dans les ganglions de la corne dorsale et les astrocytes du système nerveux central. Les cellules microgliales activées induisent une augmentation dans les cytokines pro-inflammatoires de type interleukine (IL) IL-1 $\beta$ et IL-6, le TNF $\alpha$ (facteur de nécrose tumorale) et le BDNF (facteur neurotrophique dérivé du cerveau). Ces cytokines contribuent au développement de l'hyperexcitabilité neuronale centrale qui existe en association avec la douleur neuropathique et les DCPC.

De façon intéressante, les médicaments d'anesthésie pourraient aussi être responsables d'une certaine activation des récepteurs de type NMDA et/ou des cellules gliales. Plus précisément, de hautes doses d'opioïdes seraient en mesure d'induire une augmentation du niveau de sensibilisation centrale. Chez l'animal et les volontaires humains, cette hyperalgésie induite par les opioïdes (connue en anglais comme « opioid-induced hyperalgesia » [OIH]) a été démontrée avec tous les types d'opioïdes utilisés en anesthésie pendant la chirurgie (fentanyl, rémifentanil, etc.). ${ }^{25-28}$ L'implication des récepteurs NMDA dans le développement de l'OIH a été rapportée précocement. ${ }^{29}$ Plus récemment, la capacité des opioïdes utilisés durant l'anesthésie à activer les cellules gliales a aussi été démontrée. ${ }^{19}$ L'OIH était alors dépendante de la dose et aussi de la durée d'administration.

Des études cliniques ont rapporté l'apparition d'OIH après la chirurgie. ${ }^{30-35}$ La plupart d'entre elles se sont contentées de rapporter des scores de douleur aiguë élevés, une consommation d'analgésiques accrue et une hyperalgésie postopératoire plus importante pour deux à trois jours après chirurgie quand de fortes doses d'opioïdes peropératoires étaient utilisées. Seulement deux études rapportent des résultats quant à l'influence de hautes doses d'opioïdes peropératoires sur le risque de développer des DCPC. ${ }^{36}$ De meilleures études cliniques sont nécessaires pour tirer une conclusion plus définitive sur le fait que l'OIH précoce pourrait participer au développement des DCPC. Malgré des données provenant d'études animales en ce sens, les données recueillies chez l'homme sont moins convaincantes, et ce, en dépit de publications plus nombreuses ces dernières années. 
Stratégies pharmacologiques afin de limiter l'incidence des DCPC

Bien qu'il n'existe aucun doute que l'analgésie multimodale s'avère bénéfique pour la prise en charge de la douleur aiguë, le rôle du blocage de la nociception avec l'ALR et des stratégies de traitement la douleur aiguë sur la réduction de l'incidence des DCPC demeure controversé. Dans leur revue de littérature en 2012, Van de Ven et coll. démontraient très bien que l'incidence des DCPC après amputation n'était pas significativement changée par l'ALR ou tout autre type de stratégies pharmacologiques préventives. Ils avouaient ainsi avoir rencontré quelques difficultés à formuler une conclusion ferme pour ce type spécifique de chirurgie. ${ }^{5}$ De telles incertitudes pourraient s'expliquer par la présence de douleur préopératoire et l'exposition préalable de cette population aux opioïdes. Néanmoins, leur conclusion pourrait être remise en question pour des opérés qui ne présentent aucune douleur préopératoire, ni ne consomment de fortes doses d'opioïdes avant l'acte chirurgical. Ces patients pourraient alors bénéficier des stratégies suivantes:

\section{Anesthésie régionale}

L'ALR pourrait réduire l'incidence des DCPC par différents mécanismes: ${ }^{37}$ 1) en bloquant la transmission des influx nociceptifs de la périphérie vers le niveau central, limitant ainsi l'inflammation neuronale qui active les cellules gliales, 2) en permettant une réduction majeure des doses peropératoires d'opioïdes, diminuant alors l'OIH et ses possibles conséquences à long terme. Meleine et coll., en 2012, rapportaient que, chez l'animal, un bloc nerveux de longue durée protégeait des DCPC mieux qu'une injection unique. Mais le bénéfice du bloc nerveux de longue durée était perdu quand de fortes doses d'opioïdes étaient utilisées durant l'acte chirurgical. ${ }^{38}$ D'où l'idée que les anesthésiologistes devraient choisir l'option d'une ALR adéquate pour permettre une réduction significative des doses peropératoires d'opioïdes.

Dans le contexte clinique, il est intéressant de discerner l'ALR neuraxiale (péridurale) des blocs nerveux périphériques.

L'analgésie péridurale a été recommandée depuis de nombreuses années comme la meilleure stratégie visant la prise en charge de la douleur aiguë après des chirurgies majeures comme les thoracotomies et les laparotomies. Dans ces chirurgies, il a aussi été démontré que l'analgésie péridurale permettait une réduction des DCPC. ${ }^{32,39,40}$

Dans une méta-analyse parue en 2013, Andreae et coll. ont analysé 23 études cliniques qui incluaient 1090 patients suivis durant six mois et 441 durant un an. Le but de ces études cliniques était d'évaluer l'impact de l'analgésie péridurale sur le développement des DCPC. Les données de cette étude favorisaient l'analgésie péridurale pour les thoracotomies et laparotomies (rapport de cotes $[R C] 0,33$ ), et les blocs paravertébraux pour les mastectomies (RC 0,37). ${ }^{41}$ Aucune donnée n'a cependant été rapportée quant à la durée nécessaire de l'analgésie péridurale pour avoir un impact sur les DCPC.

En ce qui concerne les blocs nerveux périphériques, plusieurs revues ${ }^{41}$ concluaient que le petit nombre d'études et de patients, et les nombreux biais (chirurgies multiples, blocs différents, etc.) ne permettaient pas de tirer une conclusion ferme concernant leur impact sur les DCPC.

Néanmoins, une étude observationnelle rapportait que l'anesthésie générale était un facteur de risque de développement de douleur aiguë après une arthroplastie de la hanche ou du genou (RC de 8,5 pour la douleur au repos et 9,0 pour la douleur à la mobilisation) lorsque comparée aux patients opérés sous ALR. ${ }^{42}$ Les mêmes patients ont été suivis longitudinalement et les auteurs ont rapporté que l'ALR, comparée à l'anesthésie générale, était capable de réduire le risque de DCPC un an après chirurgie (RC de 2,5 en faveur de l'ALR). ${ }^{43}$ Cependant, ces deux études combinaient péridurale et bloc nerveux périphérique, laissant persister un doute sur l'impact du bloc nerveux périphérique pour limiter le développement de DCPC.

Pour conclure sur l'ALR, il semble probable que les techniques d'ALR procurent une meilleure qualité d'analgésie pour la douleur aiguë postopératoire. La plupart des revues publiées durant la dernière décennie et s'intéressant à l'impact de l'ALR sur l'incidence des DCPC demeurent sujettes à controverse et ne permettent pas de tirer une conclusion définitive. S'il peut néanmoins sembler raisonnable de recommander l'analgésie péridurale dans l'espoir de diminuer les DCPC, l'utilité des blocs nerveux périphériques demeure plus incertaine.

D'autres études sont nécessaires. Le rôle de l'ALR sur l'immunomodulation et la sensibilisation neuronale sera aussi à évaluer dans le futur.

\section{Kétamine}

Les revues systématiques, tout comme les méta-analyses récentes, rapportent que la kétamine, un antagoniste des récepteurs NMDA, donnée en périopératoire, peut réduire la douleur aiguë postopératoire. ${ }^{44} \mathrm{Il}$ est aussi démontré que la kétamine peut réduire l'OIH ${ }^{34}$ pendant les $48 \mathrm{~h}$ suivant une laparotomie majeure en l'absence de péridurale. Le régime d'administration intraveineuse le plus commun pour la kétamine est: 0,2 à $0,5 \mathrm{mg} \cdot \mathrm{kg}^{-1}$ à l'induction de l'anesthésie, puis la moitié de cette dose bolus toutes les heures, à cesser une heure avant la fin de la chirurgie. La kétamine est parfois ajoutée pour $48 \mathrm{~h}$ à la solution opioïde 
contenue dans la pompe d'analgésie contrôlée par le patient (concentration de 0,5 à $1 \mathrm{mg} \cdot \mathrm{mL}^{-1}$ ). Elle peut aussi être perfusée à $0,2 \mu \mathrm{g} \cdot \mathrm{kg}^{-1} \cdot \mathrm{min}^{-1}$ dans une pompe séparée, ce qui peut s'avérer plus difficile à mettre en place dans les unités de soins hospitaliers.

Durant la dernière décennie, les résultats concernant le rôle de la kétamine intraveineuse donnée soit exclusivement pendant la chirurgie, soit durant la chirurgie et durant quelques jours supplémentaires dans le but de prévenir les DCPC ont été conflictuels. Une étude de qualité a montré des résultats positifs en laparotomie à une époque où l'analgésie péridurale n'était pas utilisée aussi couramment pour les chirurgies majeures abdominales. ${ }^{45}$ Une revue systématique récente résume bien les quelques études faites sur ce sujet. ${ }^{46}$ Klatt et coll. n'ont pu trouver que dix articles à inclure dans une métaanalyse exhaustive, le tout représentant un total de 784 patients. Trois études (303 patients) montraient un effet de la kétamine sur les DCPC. Les auteurs mentionnaient ainsi que parmi les neuf modèles testés, un seul suggérait une réduction marginale de la douleur au repos ou à la mobilisation ( $\geq 3$ sur une échelle de 10) dans une période de un à douze mois suivant l'intervention. Ils estimaient qu'il n'y a actuellement pas assez de données probantes pour conclure à une réduction des DCPC après l'utilisation de kétamine en périopératoire.

Une fois encore, comme avec l'ALR, la difficulté de mener des recherches cliniques sur les DCPC résulte en un petit nombre d'études avec peu de patients enrôlés, le tout victime de plusieurs biais. Il est donc très difficile d'émettre une conclusion ferme sur le sujet. Ici aussi, de plus amples études sont nécessaires.

\section{Autres modulateurs des récepteurs NMDA}

Le protoxyde d'azote $\left(\mathrm{N}_{2} \mathrm{O}\right)$ est aussi un antagoniste des récepteurs NMDA et peut, à ce titre, potentiellement réduire l'OIH après chirurgie chez les rongeurs ${ }^{47}$ et chez les hommes. ${ }^{48}$ Néanmoins, il n'y a pas d'étude clinique qui a évalué le rôle du $\mathrm{N}_{2} \mathrm{O}$ dans la réduction des DCPC. Seule une analyse rétrospective de données émanant d'une étude conçue à d'autres fins a suggéré un effet préventif probable de l'administration de $\mathrm{N}_{2} \mathrm{O}$ peropératoire sur les DCPC. ${ }^{49}$ Ceci ne permet donc pas, à l'heure actuelle, de recommander le $\mathrm{N}_{2} \mathrm{O}$ comme un agent préventif apte à diminuer l'incidence des DCPC.

Le magnésium est un ion qualifié de bloqueur naturel des récepteurs NMDA quand ce récepteur est au repos. Une fois le récepteur NMDA activé, le magnésium quitte sa position et laisse le calcium entrer dans le neurone postsynaptique au niveau central spinal, ce qui amorce le processus de sensibilisation centrale. L'administration de magnésium pourrait ainsi représenter une stratégie pour bloquer les récepteurs NMDA dans le système nerveux central, le tout afin de réduire la douleur aiguë et chronique après chirurgie. Pendant de nombreuses années, l'administration intrathécale de magnésium chez l'animal s'est avérée capable de bloquer la douleur aiguë et l'hyperalgésie après chirurgie. Des revues récentes de la littérature chez l'homme montrent que le magnésium intrathécal est capable de réduire de façon très intéressante les douleurs postopératoires aiguës ${ }^{50}$ mais que le magnésium intraveineux ne présente pas le même potentiel. ${ }^{51}$ Le fait que le magnésium intraveineux s'avère moins efficace pourrait être expliqué par une étude de Mercieri et coll. ${ }^{52}$ Dans cet article, les auteurs rapportent que le magnésium intraveineux ne traverse pas correctement la barrière hémato-méningée. Il ne pourrait ainsi atteindre la cible souhaitée pour l'effet analgésique recherché, soit le niveau central spinal. En ce qui concerne les DCPC, il n'y a aucune étude évaluant l'impact du magnésium sur celles-ci.

\section{Gabapentine et prégabaline}

Les gabapentinoïdes produisent une modulation inhibitrice de l'excitabilité neuronale en bloquant la sous-unité $\alpha 2-\delta$ des canaux calciques présynaptiques voltage-dépendants qui sont modulés à la hausse dans les processus de sensibilisation. Leur efficacité dans le traitement de la douleur chronique d'origine neuropathique est bien reconnue, mais leur rôle dans la prévention des DCPC est encore débattu. Le blocage de cibles présynaptiques au niveau central pourrait néanmoins diminuer l'excitabilité neuronale qui existe lorsqu'un niveau de douleur élevé apparait pendant et après la chirurgie.

Les essais cliniques ont amené des résultats controversés en regard de la réduction de l'incidence des DCPC avec la gabapentine trois et six mois après la thoracotomie, la césarienne, les chirurgies cardiaque et mammaire, et les amputations. D'un autre côté, deux revues ont indiqué que la prégabaline réduisait significativement l'incidence des DCPC après chirurgie cardiaque, du rachis, de la thyroïde et du genou à trois mois: RC 0,70 , intervalle de confiance (IC) $95 \%: 0,51$ à $0,95^{53}$ et RC 0,09 , IC $95 \% 0,02$ à $0,079.54$

La prégabaline 150-300 $\mathrm{mg}$ était amorcée avant la chirurgie et maintenue à raison de 75-150 mg BID pour deux à 14 jours. L'efficacité de la prégabaline pour réduire l'incidence des DCPC semble mieux démontrée que celle de la gabapentine, bien que plus d'études soient nécessaires pour confirmer le tout. ${ }^{55}$

Inhibiteurs des cyclo-oxygénases

Il n'y a aucun doute que les anti-inflammatoires et l'acétaminophène fassent partie intégrante de la stratégie d'analgésie multimodale périopératoire dans la prise en 
charge des douleurs aiguës postopératoires. Néanmoins, il n'y a pas de preuves que ces agents, à eux seules, puissent réduire le développement des DCPC.

\section{Agonistes alpha-2}

Les agonistes adrénergiques de type alpha- 2 comme la clonidine sont souvent utilisés pour traiter des douleurs aiguës ou chroniques, et ce, malgré leurs effets hémodynamiques indésirables. Les études animales et les études cliniques ont montré des résultats intéressants sur la douleur aiguë et l'hyperalgésie postopératoires après administration intraveineuse ou intrathécale de clonidine. Néanmoins, il n'existe pas d'étude évaluant l'effet de la clonidine périopératoire sur les DCPC.

\section{Conclusion sur les stratégies périopératoires visant à limiter le risque de DCPC}

Les DCPC représentent un phénomène bio-psycho-social complexe et il n'existe aucune mesure préventive complètement validée à ce jour. Cependant, la plupart des interventions décrites dans ce module pourraient potentiellement réduire l'incidence des DCPC et sont faciles d'utilisation par l'anesthésiologiste dans sa pratique quotidienne. Elles pourraient donc être des options utilisables quand le risque de DCPC est significatif.

Les stratégies préventives devraient cibler soit (1) des interventions à haut risque de chronicisation (amputations de membres, mastectomies radicales, thoracotomies, laparotomies, chirurgies à haut risque de dommage nerveux) ou (2) des interventions à risque de chronicisation modéré effectuées chez des patients possédant des facteurs de risque avérés (jeune âge, sexe féminin, forte intensité douloureuse préalable, utilisation préopératoire significative d'opioïdes).

L'ALR devrait être utilisée autant que possible en l'absence de contre-indication, spécialement pour les thoracotomies et les chirurgies mammaires extensives. Une perfusion périneurale / péridurale continue d'anesthésiques locaux est préférable à une administration unique.

L'ALR devrait être amorcée avant l'incision chirurgicale et maintenue pour 24-72 $\mathrm{h}$ après la chirurgie. Les fortes doses d'opioïdes peropératoires devraient être évitées lorsque possible. Les opioïdes périopératoires doivent cependant être utilisés afin d'inhiber les stimuli douloureux non couverts par l'ALR.

La kétamine intraveineuse peut être ajoutée pour une réduction accentuée de la sensibilisation centrale, spécialement quand la procédure est majeure ou nécessite l'utilisation d'opioïdes malgré l'ALR, ou quand l'ALR n'est pas réalisable.

En plus de l'ALR, une approche multimodale analgésique utilisant acétaminophène, anti-inflammatoires et opioïdes est suggérée. À ce jour, la littérature n'appuie pas clairement l'utilisation des gabapentinoïdes pour prévenir les DCPC. Cependant ils doivent être maintenus chez les patients qui en consomment en préopératoire.

\section{Scénario cas clinique}

Un patient de 52 ans doit subir une chirurgie élective non urgente pour un cancer de la portion distale de l'oesophagel'œsophage. Il est prévu d'adopter une approche combinée, soit en procédant avec des incisions thoracique et abdominale. En plus de son problème digestif, le patient souffre d'une maladie pulmonaire chronique peu sévère et présente un tabagisme en baisse depuis l'annonce de son diagnostic (est passé de 25 à 12 cigarettes par jour). Après discussion avec le patient, vous prévoyez de réaliser une anesthésie générale à l'aide de propofol $\left(2 \mathrm{mg} \cdot \mathrm{kg}^{-1}\right)$ et de sufentanil $\left(0,2 \mu \mathrm{g} \cdot \mathrm{kg}^{-1}\right)$, le tout combiné au desflurane (0,7-1 MAC). L'administration de rocuronium est aussi au programme afin de faciliter l'intubation endotrachéale $\left(0,6 \mathrm{mg} \cdot \mathrm{kg}^{-1}\right)$ et au besoin par la suite. L'insertion préopératoire d'un cathéter épidural péridural thoracique est aussi prévue. Juste avant d'entrer dans la salle d'opération, le patient vous mentionne que son épouse souffre de douleurs sous forme de brûlements dans la région axillaire, et ce, depuis une chirurgie pour néoplasie mammaire. Il dit craindre d'être victime d'une situation similaire.

\section{Directives pour compléter le module de développement professionnel continu (DPC)}

1. Lisez cet article et les références en gras.

2. Allez à http://www.cas.ca/Membres/modules-de-DPC et choisissez le module actuel: (Stratégies potentielles pour la prévention des douleurs chroniques postchirurgicales: une approche pratique).

3. Répondez aux questions à choix de réponses concernant le cas clinique.

4. Une fois que vous avez saisi toutes vos réponses, vous aurez accès aux explications d'experts pour tous les choix possibles.

5. Les participants peuvent réclamer un maximum de trois heures de DPC pour un total de 12 crédits sous la Section 3 du programme de DPC du Collège royal des médecins et chirurgiens du Canada. 
Conflicts of interest None declared.

Funding sources Medasense, Israel: investigator-initiated research grant.

\section{Conflit d'intérêt Aucun.}

Source de financement Medasense, Israel: bourse pour des recherches menées à l'initiative des chercheurs.

\section{References}

1. Macrae WA, Davies HT. Chronic postsurgical pain. In: Crombie IK, Croft PR, Linton SJ, LeResche L, Von Korff M, editors. Epidemiology of Pain. Seattle: IASP Press; 1999.

2. Macrae WA. Chronic post-surgical pain: 10 years on. Br J Anaesth 2008; 101: 77-86.

3. Kehlet H, Jensen TS, Woolf CJ. Persistent postsurgical pain: risk factors and prevention. Lancet 2006; 367: 1618-25.

4. Cregg R, Anwar S, Farquhar-Smith P. Persistent postsurgical pain. Curr Opin Support Palliat Care 2013; 7: 144-52.

5. Van de Ven TJ, Van de John Hsia HL. Causes and prevention of chronic postsurgical pain. Curr Opin Crit Care 2012; 18: 366-71.

6. Johansen A, Romundstad L, Nielsen CS, Schirmer H, Stubhaug A. Persistent postsurgical pain in a general population: prevalence and predictors in the Tromso study. Pain 2012; 153: 1390-6.

7. Buvanendran A, DeLeon A. Persistent postoperative pain after surgery. Techn Reg Anesth Pain Manag 2011; 15: 81-2.

8. Schug SA. Persistent post-surgical pain: a view from the other side of the fence. Pain 2012; 153: 1344-5.

9. Pavlin DJ, Sullivan MJ, Freund PR, Roesen K. Catastrophizing: a risk factor for postsurgical pain. Clin J Pain 2005; 21: 83-90.

10. Hanley MA, Jensen MP, Ehde DM, Hoffman AJ, Patterson DR, Robinson LR. Psychosocial predictors of long-term adjustment to lower-limb amputation and phantom limb pain. Disabil Rehabil 2004; 26: 882-93.

11. Jensen MP, Ehde DM, Hoffman AJ, Patterson DR, Czerniecki $J M$, Robinson LR. Cognitions, coping and social environment predict adjustment to phantom limb pain. Pain 2002; 95: 133-42.

12. Raja SN, Jensen TS. Predicting postoperative pain based on preoperative pain perception: are we doing better than the weatherman? Anesthesiology 2010; 112: 1311-2.

13. Katz J, Jackson M, Kavanagh BP, Sandler AN. Acute pain after thoracic surgery predicts long-term post-thoracotomy pain. Clin J Pain 1996; 12: 50-5.

14. Mogil JS, Wilson SG, Chesler EJ, et al. The melanocortin-1 receptor gene mediates female-specific mechanisms of analgesia in mice and humans. Proc Natl Acad Sci USA 2003; 100: 4867-72.

15. Haroutiunian S, Nikolajsen L, Finnerup NB, Jensen TS. The neuropathic component in persistent postsurgical pain: a systematic literature review. Pain 2013; 154: 95-102.

16. Martinez V, Ben Ammar S, Judet T, Bouhassira D, Chauvin M, Fletcher D. Risk factors predictive of chronic postsurgical neuropathic pain: the value of the iliac crest bone harvest model. Pain 2012; 153: 1478-83.

17. Ji RR, Kohno T, Moore KA, Woolf CJ. Central sensitization and LTP: do pain and memory share similar mechanisms? Trends Neurosci 2003; 26: 696-705.

18. Scholz J, Woolf CJ. The neuropathic pain triad: neurons, immune cells and glia. Nat Neurosci 2007; 10: 1361-8.

19. Romero A, Romero-Alejo E, Vasconcelos N, Puig MM. Glial cell activation in the spinal cord and dorsal root ganglia induced by surgery in mice. Eur J Pharmacol 2013; 702: 126-34.
20. Ji RR, Berta T, Nedergaard M. Glia and pain: is chronic pain a gliopathy? Pain 2013; 154(Suppl 1): S10-28.

21. Eisenach $J C$. Preventing chronic pain after surgery: who, how, and when? Reg Anesth Pain Med 2006; 31: 1-3.

22. Woolf CJ. Central sensitization: implications for the diagnosis and treatment of pain. Pain 2011; $152(3$ Suppl): S2-15.

23. Wen YR, Tan PH, Cheng JK, Liu YC, Ji RR. Microglia: a promising target for treating neuropathic and postoperative pain, and morphine tolerance. J Formos Med Assoc 2011; 110: 487-94.

24. Latremoliere A, Woolf CJ. Central sensitization: a generator of pain hypersensitivity by central neural plasticity. J Pain 2009; 10 : 895-926.

25. Cabanero D, Celerier E, Garcia-Nogales $P$, et al. The pronociceptive effects of remifentanil or surgical injury in mice are associated with a decrease in delta-opioid receptor mRNA levels: prevention of the nociceptive response by on-site delivery of enkephalins. Pain 2009; 141: 88-96.

26. Cabanero D, Campillo A, Celerier E, Romero A, Puig MM. Pronociceptive effects of remifentanil in a mouse model of postsurgical pain: effect of a second surgery. Anesthesiology 2009; 111: 1334-45.

27. Richebe $P$, Rivat $C$, Laulin JP, Maurette $P$, Simonnet $G$. Ketamine improves the management of exaggerated postoperative pain observed in perioperative fentanyl-treated rats. Anesthesiology 2005; 102: 421-8.

28. Rivat C, Laulin JP, Corcuff JB, Celerier E, Pain L, Simonnet G. Fentanyl enhancement of carrageenan-induced long-lasting hyperalgesia in rats: prevention by the N-methyl-D-aspartate receptor antagonist ketamine. Anesthesiology 2002; 96: 381-91.

29. Celerier E, Gonzalez JR, Maldonado R, Cabanero D, Puig MM. Opioid-induced hyperalgesia in a murine model of postoperative pain: role of nitric oxide generated from the inducible nitric oxide synthase. Anesthesiology 2006; 104: 546-55.

30. Fletcher D, Martinez V. Opioid-induced hyperalgesia in patients after surgery: a systematic review and a meta-analysis. Br J Anaesth 2014; 112: 991-1004.

31. Richebe P, Pouquet $O$, Jelacic S, et al. Target-controlled dosing of remifentanil during cardiac surgery reduces postoperative hyperalgesia. J Cardiothorac Vasc Anesth 2011; 25: 917-25.

32. Salengros JC, Huybrechts I, Ducart A, et al. Different anesthetic techniques associated with different incidences of chronic postthoracotomy pain: low-dose remifentanil plus presurgical epidural analgesia is preferable to high-dose remifentanil with postsurgical epidural analgesia. J Cardiothorac Vasc Anesth 2010; 24: 608-16.

33. Angst MS, Clark JD. Opioid-induced hyperalgesia: a qualitative systematic review. Anesthesiology 2006; 104: 570-87.

34. Joly $V$, Richebe $P$, Guignard $B$, et al. Remifentanil-induced postoperative hyperalgesia and its prevention with small-dose ketamine. Anesthesiology 2005; 103: 147-55.

35. Chia YY, Liu K, Wang JJ, Киo MC, Ho ST. Intraoperative high dose fentanyl induces postoperative fentanyl tolerance. Can J Anesth 1999; 46: 872-7.

36. van Gulik L, Ahlers SJ, van de Garde EM, et al. Remifentanil during cardiac surgery is associated with chronic thoracic pain 1 yr after sternotomy. Br J Anaesth 2012; 109: 616-22.

37. Rivat $C$, Bollag $L$, Richebe $P$. Mechanisms of regional anaesthesia protection against hyperalgesia and pain chronicization. Curr Opin Anaesthesiol 2013; 26: 621-5.

38. Meleine $M$, Rivat $C$, Laboureyras E, Cahana A, Richebe P. Sciatic nerve block fails in preventing the development of late stressinduced hyperalgesia when high-dose fentanyl is administered perioperatively in rats. Reg Anesth Pain Med 2012; 37: 448-54.

39. Senturk M, Ozcan PE, Talu GK, et al. The effects of three different analgesia techniques on long-term posthoracotomy pain. Anesth Analg 2002; 94: 11-5. 
40. Lavand'homme $P$, De Kock $M$, Waterloos $H$. Intraoperative epidural analgesia combined with ketamine provides effective preventive analgesia in patients undergoing major digestive surgery. Anesthesiology 2005; 103: 813-20.

41. Andreae MH, Andreae DA. Local anaesthetics and regional anaesthesia for preventing chronic pain after surgery. Cochrane Database Syst Rev 2012;10: CD007105.

42. Liu SS, Buvanendran A, Rathmell JP, et al. Predictors for moderate to severe acute postoperative pain after total hip and knee replacement. Int Orthop 2012; 36: 2261-7.

43. Liu SS, Buvanendran A, Rathmell JP, et al. A cross-sectional survey on prevalence and risk factors for persistent postsurgical pain 1 year after total hip and knee replacement. Reg Anesth Pain Med 2012; 37: 415-22.

44. Laskowski K, Stirling A, McKay WP, Lim HJ. A systematic review of intravenous ketamine for postoperative analgesia. Can J Anesth 2011; 58: 911-23.

45. De Kock $M$, Lavand'homme $P$, Waterloos $H$. 'Balanced analgesia' in the perioperative period: is there a place for ketamine? Pain 2001; 92: 373-80.

46. Klatt E, Zumbrunn T, Bandsschapp O, Girard T, Ruppen W. Intra- and postoperative intravenous ketamine does not prevent chronic pain: a systematic review and meta-analysis. Scand J Pain 2015; 7: 42-54.

47. Richebe $P$, Rivat $C$, Creton $C$, et al. Nitrous oxide revisited: evidence for potent antihyperalgesic properties. Anesthesiology 2005; 103: 845-54.

48. Echevarria $G$, Elgueta $F$, Fierro $C$, et al. Nitrous oxide $(\mathrm{N}(2) \mathrm{O})$ reduces postoperative opioid-induced hyperalgesia after remifentanil-propofol anaesthesia in humans. $\mathrm{Br} \mathrm{J}$ Anaesth 2011; 107: 959-65.

49. Chan MT, Wan AC, Gin T, Leslie K, Myles PS. Chronic postsurgical pain after nitrous oxide anesthesia. Pain 2011; 152: 2514-20.

50. Albrecht E, Kirkham KR, Liu SS, Brull R. The analgesic efficacy and safety of neuraxial magnesium sulphate: a quantitative review. Anaesthesia 2013; 68: 190-202.

51. Albrecht E, Kirkham KR, Liu SS, Brull R. Peri-operative intravenous administration of magnesium sulphate and postoperative pain: a meta-analysis. Anaesthesia 2013; 68: 79-90.

52. Mercieri $M$, De Blasi RA, Palmisani $S$, et al. Changes in cerebrospinal fluid magnesium levels in patients undergoing spinal anaesthesia for hip arthroplasty: does intravenous infusion of magnesium sulphate make any difference? A prospective, randomized, controlled study. Br J Anaesth 2012; 109: 208-15.

53. Chaparro LE, Smith SA, Moore RA, Wiffen PJ, Gilron I. Pharmacotherapy for the prevention of chronic pain after surgery in adults. Cochrane Database Syst Rev 2013; 7: CD008307.

54. Clarke H, Bonin RP, Orser BA, Englesakis M, Wijeysundera DN, $K a t z J$. The prevention of chronic postsurgical pain using gabapentin and pregabalin: a combined systematic review and meta-analysis. Anesth Analg 2012; 115: 428-42.

55. Burke SM, Shorten GD. Perioperative pregabalin improves pain and functional outcomes 3 months after lumbar discectomy. Anesth Analg 2010; 110: 1180-5. 